\title{
The Best Land Selection using Simple Additive Weighting
}

\author{
B. Ayshwarya, Firza Adi Firdiansah, Firmansyah Y. Alfian, Phong Thanh Nguyen, Wahidah \\ Hashim, K. Shankar, Satria Abadi, Sergey Kh. Peteraitis, Andino Maseleno
}

\begin{abstract}
Pringsewu Regency is an agrarian regency with the main livelihood of the population is from agro-industry agriculture. For on farm farming activities, a lot of cultivated commodities are food crops and rice crops. One of the key factors in creating equitable distribution of development or regional development and the right one result is the agricultural factor. While to know the feasibility of an agricultural area can be done by holding an assessment. The Assessment is made by Agriculture office in deciding the feasibility of agricultural areas include the assessment criteria of a region. The criteria of a region that is the type of soil, rainfall, water, temperature, and soil texture. Utilization of decision support system is very helpful in deciding the feasibility of agricultural area, and accompanied by the method of Simple Additive Weighting (SAW), this method can complete the research by finding the weight value for each attribute, then perform the ranking process that will determine the optimal alternative that is feasible for agriculture. With the decision support system with Simple Additive Weighting (SAW) method and with object oriented design using Unified Modeling Language (UML) this will make it easier for Agriculture Office and other institutions to monitor and to obtain information about agriculture that is useful for agricultural development.
\end{abstract}

Index Terms: agricultural land, simple additive weighting, rice production.

\section{INTRODUCTION}

\section{$1.1 \quad$ Background}

Today, The development of computer has encountered many changes very rapidly, along with the more complex and more diverse human need [1-5]. Computer that was originally only used by academics and the military has now been used extensively in various fields,

Revised Manuscript Received on July 22, 2019.

B. Ayshwarya, Department of Computer Science, Kristu Jayanti College, Bangalore-560043, India.

Firza Adi Firdiansah, Department of Information Systems, STMIK Pringsewu, Lampung, Indonesia.

Fimansyah Y. Alfian, Darmajaya Institute of Informatics and Business, Lampung, Indonesia.

Phong Thanh Nguyen, Department of Project Management, Ho Chi Minh City Open University (HCMCOU), Vietnam.

Wahidah Hashim, Institute of Informatics and Computing Energy, Universiti Tenaga Nasional, Malaysia.

K. Shankar, School of Computing, Kalasalingam Academy of Research and Education, Krishnankoil, India.

Satria Abadi, Department of Information Systems, STMIK Pringsewu, Lampung, Indonesia.

Sergey Kh. Peteraitis, Togliatti State University, Russia.

Andino Maseleno, Institute of Informatics and Computing Energy, Universiti Tenaga Nasional, Malaysia. E-mail: andimaseleno@gmail.com such as business, health, education, psychology, games and so on [6-9]. This encourages experts to develop computer in order to help human or even work beyond the ability of human labor [10-14]. Artificial intelligence is a part of computer science that makes the machine (computer) able to do work as and as well as human beings do. Smart system (intelligent system) is a system built using artificial intelligence techniques [15-19]. One that is studied in artificial intelligence is the theory of certainty by using the theory of Certainty Factor (CF).

Another technology in the field of certainty is the expert system (Expert System). This is a computer program that imitates expert process of thinking and knowledge in solving a particular problem. Implementation of expert systems is widely used in the field of psychology because expert system is viewed as a way of storing expert knowledge in a particular field in a computer program so that decisions can be made in intelligent reasoning. The wedge between psychology and expert system bear an area known as cognition \& psycolinguistics. Generally the knowledge is taken from a human expert in the domain and the expert system is trying to imitate the methodology and performance.

\subsection{Problem Formulation}

Based on the above background, it is determined that the problem that needs to be raised is proving the effectiveness of Simple Additive Weighting (SAW) method in designing expert system of agricultural land detection.

\subsection{The Scope of Problem}

Expert system will only prove the effectiveness of Simple Additive Weighting (SAW) method in designing expert system of agricultural land detection.

\subsection{Research Objective}

This research aimed to prove the effectiveness of Simple Additive Weighting (SAW) method in designing agricultural land detection information system.

\subsection{Research Benefit}

1. Assisting the people in increasing rice production

2. Adding reference in expert system of information technology field.

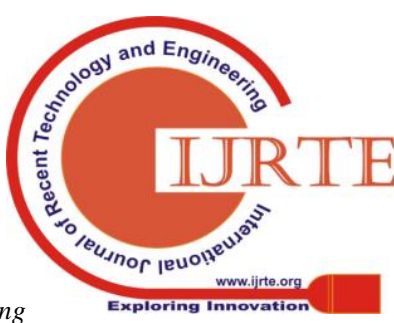




\section{THEORETICAL BASE}

\subsection{Decision Support System}

Decision support system is an interactive computer-based system, which helps decision makers to use data and various models to solve unstructured issues [20-23]. Use combination of models, analysis techniques, and information retrieval, such systems help develop and evaluate the appropriate alternatives [24-27]. Decision support system is the information system which helps identifying decision-making opportunities or provide information to help decision-making [28-31]. Basically decision support system is almost the same as the management information system because it uses the database as a data source DSS begins with SIM because it emphasizes the function of supporting the decision maker throughout its stages, although the actual decision remains the exclusive authority of the manufacturer decision [31-35]. Decision support system is more aimed at supporting management in performing analytical work in less structured situations and with less obvious criteria [36-39]. DSS is not meant for automating decision, but presents interactive tool that allows decision making performing various analyzes using available models [40-43].

\subsection{Efforts to Acquire Superior Seed}

1. Selection: selection of living being characteristic in accordance with particular purpose.

2. Hybridation: breeding two different individuals but still in one lineage.

3. Mutation: alteration of molecular chemical structure to obtain the material of heredity.

4. Transplantation: gene transplantation. .

\section{Efforts to Increase Agriculture Production}

1) Agriculture mechanism

2) new agriculture lands clearing

3). The use of new qualified fertilizers

4) Looking for right method to eradicate pest.

\section{Efforts to Increase Food Production}

\section{Panca Farming :}

a. Selection of superior seed,

rice species and age.

- Gogo rice

$-\mathrm{PB}($ Pelita Baru) 5 rice $+\mathrm{PB} 8$

- (International Rice) 36 rice + IR 64

-Cisade rice

-VOTW rice

b. good soil management

c. Fertilization

d. Irigation

e. Pest eradication

2. Agricultural Intensification. It is the business of agricultural production and the use of appropriate technology and the utilization of all means of production.
3. Agricultural Extensification. It is an effort to increase agricultural yield by expanding new agricultural land, such as clearing forests and shrubs, clearing areas around swamps, and clearing 4. abandoned agricultural areas.

Agricultural diversification. It is an effort to diversify farming through an intercropping system.

\subsection{Research Location}

The change of agriculture area is obtained by overlaying intersect method and by clippling method to obtain land change per sub-district. However, for rainfed lowland area encountered a wide increase. Decrease in area of irrigated paddy field by $1 \mathrm{Ha}$, while for the dry land had decreased by 3 $\mathrm{Ha}$ and the increase of area for rainfed lowland area of 2 Ha. The increase of rainfed lowland area is likely due to land conversion from dryland and mixed dryands located around the Ambarawa sub-district due to the data processing, the sub-district encounters significant increase of $2.5 \mathrm{Ha}$. From the research results above can be obtained mapping agricultural land that can improve rice production in Pringsewu District Ambarawa District.

\subsection{Simple Additive Weighting (SAW)}

Simple additive weighting method is often also known as the weighted summing method. The basic concept of SAW is to find the weighted sum of the performance of each alternative at all. The SAW method requires the process of normalizing the decision matrix (X) to a scale comparable to all existing alternative ratings.

\section{RESEARCH METHODS}

\subsection{Data Collection Technique}

Data collection is done by the following methods:

1. Literature study, this method is the collection of data and information by reference reading books or ebook and website related to this research.

2. Observation method: this method is used by observing the quality of agricultural land in increasing rice production while observing the needs associated with rice production.

3. Interview method. This method is used by interviewing the farmers to obtain the necessary data for the purpose of designing expert systems of deciding agricultural land quality.

\subsection{Design model}

The design stage is done by using waterfall method. The core of waterfall method is the processing of a system performed sequentially or linearly. So if the stage one has not been done then it will not be able to do stage 2, 3 and so on. Automatically the 3rd stage will be done if the first and second stage have been done.

\subsection{Data Analysis}

To perform the analysis of data, it can be used descriptive and interpretative methods,

Descriptive analysis is done by describing all events and phenomena seen during the research, while interpretative model is used to illustrate 
conclusions by interpreting the existing phenomena.

\subsection{Problem Analysis}

Agriculture Office of Pringsewu Regency is an agency that gives the information on development of future agriculture planning, so that people can do agricultural development to achieve good agricultural yield, to realize food self-sufficiency and improvement of raw materials processing industry into finished goods. To realize development planning information is needed the determination of agricultural areas. Agriculture gives weighting value for each criterion based on its importance level, that is:

Table 1. Weight Score

\begin{tabular}{|c|c|}
\hline Bobot & Nilai \\
\hline Very low (SR) & 1 \\
\hline Low (R) & 2 \\
\hline Medium (C) & 3 \\
\hline High (T) & 4 \\
\hline Very High (ST) & 5 \\
\hline
\end{tabular}

To solve the problem with simple additive weighting method, Specify the criteria to be referenced in decision making, ie $\mathrm{Ci}$..

The criteria used to determine a region worthy or not to serve as agricultural areas, namely:

Table 2. Criteria

\begin{tabular}{|l|l|l|}
\hline Criteria & Weight & Score \\
\hline (C1) Soil Type & Very High (ST) & 5 \\
\hline (C2) Soil Texture & High (T) & 4 \\
\hline (C3) Rainfall & Fair (C) & 3 \\
\hline (C4) Temperature & Low (R) & 2 \\
\hline
\end{tabular}

Table 3. Soil type criteria (C1)

\begin{tabular}{|l|l|l|l|l|l|}
\hline \multirow{2}{*}{$\begin{array}{c}\text { Alternativ } \\
\text { e }\end{array}$} & \multicolumn{5}{|c|}{ Criteria } \\
\cline { 2 - 6 } & $\mathrm{C} 1$ & $\mathrm{C} 2$ & $\mathrm{C} 3$ & $\mathrm{C} 4$ & $\mathrm{C} 5$ \\
\hline A1 & 4 & 5 & 3 & 3 & 4 \\
\hline A2 & 5 & 5 & 3 & 3 & 4 \\
\hline A3 & 3 & 1 & 4 & 4 & 3 \\
\hline A4 & 2 & 2 & 5 & 3 & 1 \\
\hline
\end{tabular}

Table 4. Soil texture criteria (C2)

\begin{tabular}{|l|l|l|l|}
\hline No & Soil texture & Weight & Score \\
\hline 1 & Soft and wet & Very Low & 1 \\
\hline 2 & Clayey & Low & 2 \\
\hline 3 & Loose & Very High & 5 \\
\hline
\end{tabular}

Table 5. Rainfall criteria

\begin{tabular}{|l|l|l|l|}
\hline No & Rainfall & Weight & Score \\
\hline 1 & Low & Low & 2 \\
\hline 2 & Medium & Medium & 3 \\
\hline 3 & High & High & 4 \\
\hline 4 & Very High & Very High & 5 \\
\hline
\end{tabular}

Table 6. Temperature criteria

\begin{tabular}{|l|l|l|l|}
\hline No & Temperature & Weight & Score \\
\hline 1 & Cold & Low & 2 \\
\hline 2 & Normal & Medium & 3 \\
\hline 3 & Warm & High & 4 \\
\hline 4 & Hot & Very High & 5 \\
\hline
\end{tabular}

Table 7. Irigation criteria

\begin{tabular}{|l|l|l|l|}
\hline No & $\begin{array}{l}\text { Irigation } \\
\text { System }\end{array}$ & Weight & Score \\
\hline 1 & Traditional & Very Low & 1 \\
\hline 2 & Water pump & Low & 2 \\
\hline 3 & Local & Medium & 3 \\
\hline 4 & Spray & High & 4 \\
\hline 5 & Surface & Very High & 5 \\
\hline
\end{tabular}

Deciding each alternative's compatibility rating on each criteria. The compatile rate data from each alternative can be seen in table 9.

Table 8. Compatibility Rating from Each Alternative in Each Criteria

\begin{tabular}{|l|l|l|l|}
\hline No & Soil Type & Weight & Score \\
\hline 1 & Clay & Low & 2 \\
\hline 2 & $\begin{array}{l}\text { Organosol/Peat } \\
\text { Soil }\end{array}$ & Medium & 3 \\
\hline 3 & Humus Soil & High & 4 \\
\hline 4 & Aluvial Soil & $\begin{array}{l}\text { Very } \\
\text { High }\end{array}$ & 5 \\
\hline
\end{tabular}

\subsection{Accuracy test (Matrix)}

So to obtain the Ai score on qualified agricultural land mapping at the Pringsewu District Agricultural Service are as follows:

Formula :

$$
I_{i}=\sum_{j=1}^{n} w j \cdot r_{i j}
$$

Alternative score in each criterion

\begin{tabular}{|c|c|c|c|c|c|c|}
\hline \multirow{3}{*}{ Alternative } & \multicolumn{5}{|c|}{ Criteria } \\
\cline { 3 - 7 } & & $\mathbf{C}_{\mathbf{1}}$ & $\mathbf{C}_{\mathbf{2}}$ & $\mathbf{C}_{\mathbf{3}}$ & $\mathbf{C}_{\mathbf{4}}$ & $\mathbf{C}_{\mathbf{5}}$ \\
\hline & $\mathrm{A}_{\mathbf{1}}$ & 4 & 5 & 3 & 3 & 4 \\
\hline & $\mathrm{A}_{2}$ & 5 & 5 & 3 & 3 & 4 \\
\hline & $\mathrm{A} 3$ & 3 & 1 & 4 & 4 & 3 \\
\hline & $\mathrm{A}_{4}$ & 2 & 2 & 5 & 3 & 1 \\
\hline
\end{tabular}

Where :

$$
\begin{aligned}
\mathrm{R}= & {\left[\begin{array}{lllll}
0.8 & 1 & 0.6 & 0.75 & 1 \\
1 & 1 & 0.6 & 0.75 & 1 \\
0.6 & 0.2 & 0.8 & 1 & 0.75 \\
0.4 & 0.4 & 1 & 0.75 & 0.25
\end{array}\right] } \\
\mathrm{A} 1=(0.8 \times 0.3)+(1 \mathrm{x} & \\
& \begin{array}{ll}
0.2)+(0.6 \times 0.2)+(0.75 \mathrm{x} \\
0.15)
\end{array} \\
& \begin{array}{l}
\text { Published By: } \\
\text { Blue Eyes Intelligence Engineering } \\
\text { \& Sciences Publication }
\end{array}
\end{aligned}
$$


$+(1 \times 0.15)$

$$
\begin{aligned}
\mathrm{A} 2= & (1 \times 0.3)+(1 \times 0.2)+(0.6 \times 0.2)+(0.75 \times 0.15)+(1 \\
& \times 0.15)
\end{aligned}
$$

$$
\begin{aligned}
\mathrm{A} 3= & (0.6 \times 0.3)+(0.2 \times 0.2)+(0.8 \times 0.2)+(1 \times 0.15) \\
& +(0.75 \times 0.15)
\end{aligned}
$$$$
\mathrm{A} 4=(0.4 \times 0.3)+(0.4 \times 0.2))+(1 \times 0.2)+(0.75 \times 0.15)+
$$$$
(0.25 \times 0.15)
$$

$$
\begin{aligned}
& \mathrm{A} 1=0.24+0.2+0.12+0.1125+0.15=0.8225 \\
& \mathrm{~A} 2=0.3+0.2+0.12+0.1125+0.15=0.8825 \\
& \mathrm{~A} 3=0.18+0.04+0.16+0.15+0.1125=0.6425 \\
& \mathrm{~A} 4=0.12+0.08+0.2+0.1125+0.0375=0.55
\end{aligned}
$$

The greatest score was in A2, so A2 alternative was the selected alternative as the best alternative. In other words, maintanance of information technology means will be selected as the solution for the best land selection.

\subsection{Program Implementation}

In the criteria form used alternative data and criteria as shown in figure 1. In the weight form that is used to calculate a criterion and find the weight of an alternative as shown in figure 2.

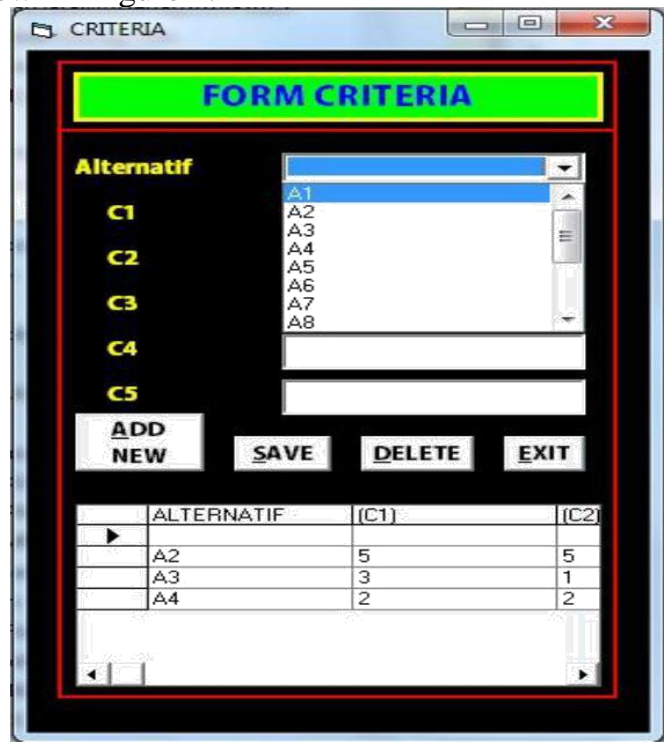

Figure 1. Criterial form

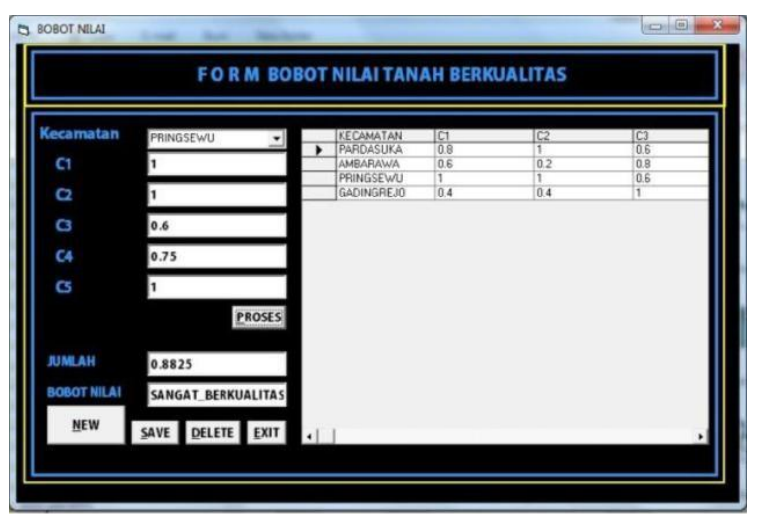

Figure 2. Weight form

\section{CONCLUSION}

The decision support system for deciding the feasibility of agriculture can be used to:

1. Implementation of decision support system with simple additive weighting method which is done based on the results of ranking from the largest alternative until the smallest. The results of the decision support system process of deciding the feasibility of this area can be used as a consideration to determine the area that can be used as agricultural areas.

2. Completion of eligibility criteria of agricultural area was done by calculating the weight of the value of each criterion those are soil type, soil texture, rainfall, temperature and irrigation system.

3. Application of decision support system is designed based on the determination of criteria and calculations that have been obtained, and use design in the form of use case and activity diagram.

\section{REFERENCES}

[1]. Sychugov, A. A., Akhmetshin, E. M., Grishin, V. M., Shpakova, R. N., \& Plotnikov, A. V. (2019). Algorithm determine trust value to the distributed information systems elements. Journal of Mechanical Engineering Research and Developments, 42(2), 6-9. doi:10.26480/jmerd.02.2019.06.09

[2]. Voronkova, O. Y., Akhmetshin, E. M., Sycheva, I. N., Shpakova, R. N., Pashkova, E. Y., \& Poltarykhin, A. L. (2018). Economic mechanism of regulating land relations in the agricultural sector of Russia. European Research Studies Journal, 21(4), 280-291.

[3]. Ibatova, A. Z. (2018). Implementation of ISO principles in engineers' training. International Journal of Civil Engineering and Technology, 9(3), 515-521.

[4]. Tri Susilowati, P. Manickam, G. Devika, K. Shankar, Latifah, Muhamad Muslihudin, Wahidah Hashim, Miftachul Huda, Aleksandr Aleeksevich Korostelev, Andino Maseleno, Decision Support System for Determining Lecturer Scholarships for Doctoral Study Using CBR (Case-Based Reasoning) Method, International Journal of Recent Technology and Engineering (IJRTE), 2019. pp. 3281-3290.

[5]. Muhamad Muslihudin, M. Ilayaraja, K. Sathesh Kumar, K. Shankar, Jauharotun Jamilah, Dita Novitasari, Miftachul Huda, Wahidah Hashim, Irina V. Rudenko, Andino Maseleno, Decision Support System in Kindergarten Selection using TOPSIS Method, International Journal of Recent Technology and Engineering (IJRTE), 2019. pp.3291-3298.

[6]. Muhamad Muslihudin, G. Devika, P. Manickam, K. Shankar, Dian Permana Putra, Eki Pramudia Sukarno Putra, Miftachul Huda, Wahidah Hashim, Oksana P. Denisova, Andino Maseleno, Expert System in Determining Baby Disease using Web Mobile-based Weighted Product Method, International Journal of Recent Technology and Engineering (IJRTE), 2019. pp.3299-3308.

[7]. Muhamad Muslihudin, K. Sathesh Kumar, M. Ilayaraja, K. Shankar, Lailaturrohmah, Dian Permana Putra, Wahidah Hashim, Andino Maseleno, Expert System in Determining the Quality of Nutmeg Breed using Website-Based Forward Chaining Methods, International Journal of Recent Technology and Engineering (IJRTE), 2019. pp.3309-3318.

[8]. Muhamad Muslihudin, S. Hemalatha, K. Shankar, Eswaran Perumal, Nofiyanti, Satria Abadi, Wahidah Hashim, Andino Maseleno, Application of

Expert System for

Determining Export Quality

Pepper Seeds using 
Website-Based Forward Chaining Method, International Journal of Recent Technology and Engineering (IJRTE), 2019. pp. 3319-3329.

[9]. Muhamad Muslihudin, Rizky Purnama, Wahidah Hashim, Andino Maseleno, Selection of Temporary Landfill using Fuzzy Multiple Attribute, International Journal of Innovative Technology and Exploring Engineering, 2019. pp.598-604

[10]. Muhamad Muslihudin, Siti Mukodimah, Erma Dwiyani, Trisnawati, Wahidah Hashim, Andino Maseleno, Fuzzy Logic Prediction of Dengue Hemorrhagic Fever Distribution in Pringsewu Region, International Journal of Innovative Technology and Exploring Engineering, 2019. pp.605-612.

[11]. S. Senthil, B. Ayshwarya, Prediction of Lung Cancer using Blue Whale Optimizer Algorithm with Neural Network Classifier, Journal of Advanced Research in Dynamical and Control Systems, Volume 11, 02-Special Issue, 2019. pp. 1737-1748.

[12]. Narges Bahrami, Sifeng Liu, Vadim Vitalievich Ponkratov, Phong Thanh Nguyen, Andino Maseleno, Stephen Berti, Novel Load Management for Renewable Generation Sources/Battery System through Cut Energy Expenditure and Generate Revenue, International Journal of Ambient Energy, Taylor and Francis Online, 2019.

[13]. Aravindhan Surendar, J. Muralidharan, Ali Dehghan Saee, Andino Maseleno, Aleksandr Alekseevich Rudenko, David Ros, Mathematical modelling of free convection in an ellipse-rectangular annulus filled with nanofluid using LBM, Thermal Science and Engineering Progress, Elsevier, 2019

[14]. Aditya Mulawarman, Ajat Sudrajat, Nedi Hendri, Karnawi Kamar, Dedi Mulyadi, Gunawan Budiyanto, Miftachul Huda, Aliza Abdul Latif, Andino Maseleno, FMADM for determining superior commodity at agroindustry area, International Journal of Engineering and Technology(UAE), Vol. 7, No. 4, 2018, pp. 4667-4673.

[15]. Aprianti Putri Sujana, Andri Sahata Sitanggang, Andino Maseleno, Application of E-Transport through Android-Based Ticketing Applications, Journal of Advanced Research in Dynamical and Control Systems, Issue 13-Special Issue, 2018, pp. 1347-1356.

[16]. Pardimin, Apriadi, Widhiya Ninsiana, M. Ihsan Dacholfany, Karnawi Kamar, Kamarul Shukri Mat Teh, Miftachul Huda, April Lia Hananto, Muhammad Muslihudin, K Shankar, Natalia V. Kamenez, Andino Maseleno, Developing Multimedia Application Model for Basic Mathematics Learning, Journal of Advanced Research in Dynamical and Control Systems, Issue 14-Special Issue, 2018, pp. 1347-1356

[17]. Natalia V. Kamenez, Olga Igorevna Vaganova, Zhanna Venediktovna Smirnova, Marina Nikolaevan Bulayeva, Ekaterina Andreevna Kuznetsova, Andino Maseleno, Experience of the use of electronic training in the educational process of the Russian higher educational institution, International Journal of Engineering and Technology(UAE), Vol. 7, No. 4, pp. 4085-4089, 2018.

[18]. Olga Igorevna Vaganova, Ludmila N. Zanfir, Zhanna Venediktovna Smirnova, Elena Aleksandrovna Chelnokova, Svetlana Nikolaevna Kaznacheeva, Andino Maseleno, On the linguistic training of future teachers of unlike specialties under the conditions of Russian professional education, International Journal of Engineering and Technology(UAE), Vol. 7, No. 4, pp. 4090-4095, 2018.

[19]. Olga Igorevna Vaganova, Natalia V. Kamenez, Vinnikova Irinia Sergeevna, Ekaterina Vladimirovna Vovk, Zhanna Venediktovna Smirnova, Andino Maseleno, Possibilities of information technologies to increase quality of educational services in Russia, International Journal of Engineering and Technology(UAE), Vol. 7, No. 4, pp. 4096-4102, 2018.

[20]. Zhanna Venediktovna Smirnova, Ludmila N. Zanfir, Olga Igorevna Vaganova, Natalia Vasilevna Bystrova, Nina Vladimirovna Frolova, Andino Maseleno, WorldSkills as means of improving quality of pedagogical staff training, International Journal of Engineering and Technology(UAE), Vol. 7, No. 4, pp. 4103-4108, 2018

[21]. Abdul Hamid, Ajat Sudrajat, Razaleigh Muhamat Kawangit, Abdul Ghafar Don, Miftachul Huda, Burhanuddin Jalal, Wahyu Akbar, Azura Onn, Andino Maseleno, Determining basic food quality using SAW, International Journal of Engineering and Technology(UAE), Vol. 7, No. 4, pp. $3548-3555,2018$.

[22]. Noca Yolanda Sari, Miftachul Huda, Kamarul Shukri Mat Teh, Anggia Sari, Ramona Ramli, Andino Maseleno, Decision support system for determining chili plant using fuzzy multiple attribute decision making, International Journal of Engineering and Technology(UAE), Vol. 7, No. 4, pp. 3556-3562, 2018.

[23]. Oktafianto, Ajat Sudrajat Kawangit, Razaleigh Muhamat Kawangit, Abdul Ghafar Don, Miftachul Huda, Amel Dhea Saputri,Aliza Abdul Latif, Andino Maseleno, Determining housing location using weighted product, International Journal of Engineering and Technology(UAE), Vol. 7, No. 4, pp. 3563-3568, 2018.

[24]. Akhmetshin, E., Ilyina, I., Kulibanova, V., \& Teor, T. (2019). Special aspects of master data-based integrated management of region reputation in modern IT environment. Paper presented at the IOP Conference Series: Materials Science and Engineering, 497(1) doi:10.1088/1757-899X/497/1/012022

[25]. Atova, A. Z., Sitdikov, F. F., \& Klychova, G. S. (2018). Reporting in the area of sustainable development with information technology application. Management Science Letters, 8(7), 785-794. doi:10.5267/j.msl.2018.5.008

[26]. Sychugov, A. A., Akhmetshin, E. M., Grishin, V. M., Shpakova, R. N., \& Plotnikov, A. V. (2019). Algorithm determine trust value to the distributed information systems elements. Journal of Mechanical Engineering Research and Developments, 42(2), 6-9. doi:10.26480/jmerd.02.2019.06.09.

[27]. Satria Abadi, Akmal Hawi, Akla, Ihsan Dacholfany, Miftachul Huda, Kamarul Shukri Mat Teh, Jaki Walidi, Wahidah Hashim, Andino Maseleno, Identification of Sundep, Leahopper and Fungus of Paddy by using Fuzzy SAW Method, International Journal of Pharmaceutical Research, Volume 11, Issue 1, January - March 2019.

[28]. Andino Maseleno, Miftachul Huda, Kamarul Azmi Jasmi,Bushrah Basiron, Ismail Mustari, Abdul Ghaffar Don, Roslee bin Ahmad, Hau-Kashyap Approach for Student's Level of Expertise, Egyptian Informatics Journal, Elsevier, Vol. 20, Issue 1, March 2019, pp. 27-32.

[29]. Liang Zhou, Hesam Kamyab, Aravindhan Surendar, Andino Maseleno, Aygul Z. Ibatova, Shreeshivadasan Chelliapan, Nima Karachi, Zohreh Parsaee, Novel Z-scheme composite $\mathrm{Ag} 2 \mathrm{CrO} / \mathrm{NG} /$ polyimides as high performance nano catalyst for photoreduction of $\mathrm{CO} 2$ : Design, fabrication, characterization and mechanism, Journal of Photochemistry and Photobiology A: Chemistry, Elsevier, Volume 368, 1 January 2019, pp 30-40.

[30]. Muhamad Rusliyadi, Azaharaini bin $\mathrm{Hj}$. Mohd. Jamil, Marini Othman, Andino Maseleno, Ratna Tri Kumalasari, Agricultural Extension Policy, Agricultural Growth and Poverty Reduction in Indonesia, International Journal of Engineering and Technology (UAE), Vol. 7, No. 4, 2018, pp. $5539-5550$.

[31]. Gunawan Budiyanto, Sri Ipnuwati, Sayyid Azam Al Gifari, Miftachul Huda, Burhanuddin Jalal, Aliza Abdul Latif, Andino Maseleno, April Lia Hananto, Web based expert system for diagnosing disease pest on banana plant, International Journal of Engineering and Technology(UAE), Vol. 7, No. 4, 2018, pp. 4715-4721.

[32]. Elisabet Yunaeti Anggraeni, Pardimin, Ihsan Dacholfany, Akla, Miftachul Huda, Kamarul Shukri Mat Teh, Aminudin Hehsan, Juhazren Junaidi, Farahwahida Mohd Yusof, Hafiza Abas, Mohd Fauzi Abu Husin, Dina Apriani, Aliza Abdul Latif, Andino Maseleno, Modelling effectivenes of IS learning methodology with AHP method, International Journal of Engineering and Technology(UAE), Vol. 7, No. 4, 2018, pp. 4708-4714.

[33]. Fauzi, Miftachul Huda, Kamarul Shukri Mat Teh, Zulkiflee Haron, Mohd. Nasir Ripin, Aminudin Hehsan, Hafiza Abas, Muhamad Rafiq, July Irawan, Satria Abadi, Andino Maseleno, The

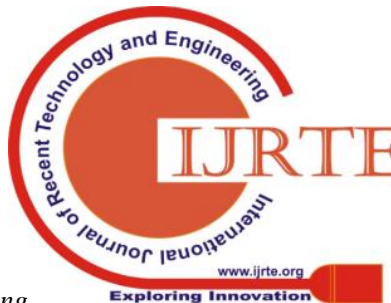
\& Sciences Publication 
Design of Fuzzy Expert System Implementation for Analyzing Transmissible Disease of Human, International Journal of Pharmaceutical Research, Vol. 10, Issue 4, 2018.

[34]. Mohamed Elhoseny, K. Shankar, S.K. Lakshmanaprabu, Andino Maseleno, N. Arunkumar, Hybrid Optimization with Cryptography Encryption for Medical Image Security in Internet of Things, Neural Computing and Applications, Springer, October 2018, pp. 1-15.

[35]. E. Laxmi Lydia, P. Krishna Kumar, K. Shankar, S.K. Lakshmanaprabu, R.M. Vidhyavathi, Andino Maseleno, Charismatic Document Clustering through Novel K-Means Non-negative Matrix Factorization (KNMF) Algorithm using Key Phrase Extraction, International Journal of Parallel Programming, Springer, 2018, pp. 1-19.

[36]. K. Shankar, S.K. Lakshmanaprabu, Deepak Gupta, Andino Maseleno, Victor Hugo C. De Albuquerque, Optimal feature-basedmulti-kernel SVM approach for thyroid disease classification, The Journal of Supercomputing, Springer, Vol. 74, no. 259, 2018, pp. 1-16.

[37]. M. Miftakul Amin, Adi Sutrisman, Deris Stiawan, Andino Maseleno, Design Restful WebService of National Population Database for supporting E-health interoperability service, Journal of Theoretical and Applied Information Technology, vol. 96, issue 15, 2018.

[38]. A.H. Motlagh, S.V. Klyuev, Aravindhan Surendar, Aygul Z. Ibatova, Andino Maseleno, Catalytic Gasification of Oil Sludge with Calcined Dolomite, Petroleum Science and Technology, Taylor and Francis, pp. 1-5, 2018.

[39]. Aravindhan Surendar, Alireza Bozorgian, Andino Maseleno, Lubov K. Ilyashenko, Meysam Najafi, Oxidation of Toxic Gases via Ge-B36N36 and Ge-C72 Nanocages as Potential Calaysts, Inorganic Chemistry Communications, Elsevier, Vol. 96, October 2018, pp. 206-210.

[40]. Abdolhamid Namdarian, Amin Goljanian Tabrizi, Andino Maseleno, Abdolkhaled Mohammadi, Seyyed Ebrahim Mossavifard, One step synthesis of rGO-Ni3S2 nano-cubes composite for high-performance supercapacitor electrodes, International Journal of Hydrogen Energy, Elsevier, vol. 43, Issue 37, 13 September 2018, pp.17780-17787.

[41]. Aravindhan Surendar, Lina G. Akhmetov, Lubov K. Ilyashenko, Andino Maseleno, Vahid Samavatian, Effect of thermal cycle loadings on mechanical properties and thermal conductivity of a porous lead-free solder joint, IEEE Transactions on Components, Packaging, and Manufacturing Technology, 2018, pp. 1769-1776.

[42]. Aravindhan Surendar, Vahid Samavatian, Andino Maseleno, Aygul Z. Ibatova, Majid Samavatian, Effect of solder layer thickness of thermo-mechanical reliability of a power electronic system, Journal of Material Science: Materials in Electronics, Springer, September 2018, Volume 29, Issue 17, pp. 15249-15258.

[43]. Andino Maseleno, Alicia Y.C. Tang, Moamin A. Mahmoud, Marini Othman, K. Shankar, Big Data and E-Learning in Education, International Journal of Computer Science and Network Security, 2018, Vol. 18, No. 5, pp. 171- 174 . 